\title{
Ultrasonography and colour Doppler in juvenile idiopathic arthritis: Diagnosis and follow-up of ultrasound-guided steroid injection in the wrist
}

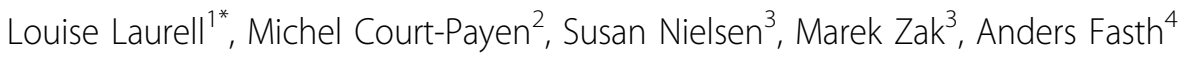 \\ From 18th Pediatric Rheumatology European Society (PReS) Congress \\ Bruges, Belgium. 14-18 September 2011
}

\section{Background}

Wrist inflammation commonly causes growth deformation and is an indicator of poor outcome in JIA [1]. Due to the anatomical complexity of the wrist, defining the exact anatomical location of synovial inflammation and performing palpation-guided injections are difficult.

\section{Aim}

To assess the usefulness of ultrasonography (US) of the wrist for detection of synovial hypertrophy and hyperaemia, as well as for guidance and efficacy evaluation of steroid injections in patients with JIA.

\section{Methods}

15 symptomatic wrists in 11 patients with JIA, 10 girls and 1 boy between 2 and 16 years (median 12.5 years), were assessed clinically and by Doppler-US before and after ( 1 - 4 weeks) US-guided steroid injection. The presence (no normalization) or absence (normalization) of

Table 1 US diagnosis of synovial hypertrophy and hyperaemia in 15 wrists before injection

\begin{tabular}{llll}
\hline Compartment & $\begin{array}{l}\text { Number of } \\
\text { wrists }\end{array}$ & $\begin{array}{l}\text { Synovial } \\
\text { hypertrophy }\end{array}$ & Hyperaemia \\
\hline Radio-carpal joint & 13 & $13(87 \%)$ & $12(80 \%)$ \\
Mid-carpal joint & 8 & $8(53 \%)$ & $7(47 \%)$ \\
Tendon sheaths & 5 & $5(33 \%)$ & $4(27 \%)$ \\
All & 26 & $26(100 \%)$ & $23(88 \%)$ \\
compartments & & & \\
\hline
\end{tabular}

\footnotetext{
* Correspondence: Louise.Laurell@skane.se

'Department of Paediatrics, Skåne University Hospital, Lund University, Sweden

Full list of author information is available at the end of the article
}

Table 2 Effect on synovial hypertrophy 1 week and 4 weeks after US-guided steroid injection

\begin{tabular}{llllll}
\hline $\begin{array}{l}\text { Normalization } \\
\text { Compartment }\end{array}$ & $\begin{array}{l}\text { Number } \\
\text { injected }\end{array}$ & $\begin{array}{l}\text { Result after 1 } \\
\text { week } \\
\text { Normalization }\end{array}$ & $\begin{array}{l}\text { Result after 4 } \\
\text { weeks }\end{array}$ \\
\cline { 3 - 6 } & & Yes & No & Yes & No \\
\hline Radio-carpal joints & 12 & $6 / 12$ & $6 / 12$ & $10 / 12$ & $2 / 12$ \\
Mid-carpal joints & 5 & $(50 \%)$ & $(50 \%)$ & $(83 \%)$ & $(17 \%)$ \\
Tendon sheaths & 4 & $2 / 5$ & $3 / 5$ & $4 / 5$ & $1 / 5$ \\
& & $(40 \%)$ & $(60 \%)$ & $(80 \%)$ & $(20 \%)$ \\
All compartments & 21 & $4 / 4$ & $0 / 4$ & $4 / 4$ & $0 / 4$ \\
& & $(100 \%)$ & $(0 \%)$ & $(100 \%)$ & $(0 \%)$ \\
& $12 / 21$ & $9 / 21$ & $18 / 21$ & $3 / 21$ \\
& & $(57 \%)$ & $(43 \%)$ & $(86 \%)$ & $(14 \%)$ \\
\hline
\end{tabular}

synovial hypertrophy and Doppler flow (hyperaemia) after treatment was recorded.

\section{Results}

Inflammation was found in all 15 wrists. Table 1-2 show involved anatomical structures and the effects of USguided steroid injections.

\section{Conclusion}

US enabled exact anatomical location of synovial inflammation, guidance of steroid injections and was valuable for follow-up examinations. Our findings suggest that in children with JIA US should be performed before wrist injections and to guide those procedures.

\footnotetext{
Author details

'Department of Paediatrics, Skåne University Hospital, Lund University, Sweden. ${ }^{2}$ Department of Diagnostic Imaging, Gildhøj Private Hospital, University of Copenhagen, Denmark. ${ }^{3}$ Department of Paediatrics, Rigshospital, University of Copenhagen, Denmark. ${ }^{4}$ Department of Paediatrics, University of Gothenburg, Sweden.
} 


\section{Reference}

1. Ravelli A, Martini A: Juvenile Idiopathic Arthritis. Lancet 2007, 369:767-78.

doi:10.1186/1546-0096-9-S1-P41

Cite this article as: Laurell et al.: Ultrasonography and colour Doppler in juvenile idiopathic arthritis: Diagnosis and follow-up of ultrasound-

guided steroid injection in the wrist. Pediatric Rheumatology 2011 9(Suppl 1):P41.

Submit your next manuscript to BioMed Central and take full advantage of:

- Convenient online submission

- Thorough peer review

- No space constraints or color figure charges

- Immediate publication on acceptance

- Inclusion in PubMed, CAS, Scopus and Google Scholar

- Research which is freely available for redistribution 